7. Reprod. Fert. (1975) 45, 91-99

\title{
EVIDENCE OF PROLACTIN CELL DEFICIENCY IN CONNECTION WITH LOW REPRODUCTIVE EFFICIENCY OF FEMALE 'TORPID’ MICE
}

\author{
H. C. DUNG \\ Department of Anatomy, The University of Texas Health Science Center at \\ San Antonio, 7703 Floyd Curl Drive, San Antonio, Texas 78284, U.S.A.
}

(Received 16th December 1974)

\begin{abstract}
Summary. The pituitary of female 'torpid' mice at the age of sexual maturity was deficient in prolactin cells. This deficiency is thought to contribute to the infertility of the affected mice.
\end{abstract}

\section{INTRODUCTION}

The 'torpid' mouse was first described in 1965 by Dickie. It resulted from a single recessive gene mutation which occurred in the DBA/2J strain. Homozygous affected animals were known to have abnormal behaviour and were classified as neurological mutants (Sidman et al., 1965). These mutants were also shown to have low reproductive efficiency, runting, and other clinical symptoms. The pathology underlying the clinical symptoms was unknown. It is important that investigations be undertaken to determine the pathogenesis of the clinical symptoms found in the mutants. Only then can these mutants be considered as useful experimental models for similar diseases in man. Without such knowledge, the value of the mutants for experimental studies remains limited.

Since the female mutants were known to show low reproductive efficiency and poor growth, a number of studies were carried out in our laboratory to determine if there were pathological changes in the pituitary and ovaries.

\section{MATERIALS AND METHODS}

Sources of the mutant stock and body weights

The animals used were all bred in this laboratory. The original stock were obtained from the Jackson Laboratory, Bar Harbor, Maine, in 1967. The mutants were identified by their abnormal behaviour and smaller body weight than that of normal littermates after 18 days of age. The curves for body weight at different ages were obtained following the method previously described by Dung \& Swigart (1971).

\section{Vaginal smears}

Six normal and six 'torpid' female mice were randomly chosen for study of the oestrous cycle. The age of the animals was between 3 and 4 months. The 
vagina was washed with a small quantity of distilled water with a clean pipette and vaginal smears were made daily for 30 days. The mouse was considered to be in oestrus if the smear contained predominantly cornified epithelial cells.

\section{Organ weights}

Mice were killed with an overdose of sodium pentobarbital and the pituitary, ovaries, uterus, brain, heart, kidney, and spleen were removed. After cleaning from surrounding fat and connective tissue under a dissecting microscope, the tissues were frozen in wells drilled in $\frac{3}{4}$-in. aluminium plate packed in powdered dry ice. The tissues were freeze-dried and their weights were $c_{\text {. ermined as }}$ described previously (Dung \& Swigart, 1971).

\section{Histological and pathological studies}

Four normal and nine 'torpid' females between 3 and 4 months of age were prepared by cardiac perfusion under appropriate anaesthesia with mammalian physiological saline followed by $10 \%$ neutral formol saline or Bouin's fixative. After perfusion, the pituitary, ovaries, thyroid, adrenal glands, brain, thymus, spleen, submaxillary glands with lymph nodes, and pancreas were removed and allowed to remain in the fixative overnight. The tissues were washed, dehydrated, and embedded in paraffin wax $\left(53 \pm 1^{\circ} \mathrm{C}\right)$. Blocks of all tissues except brain were cut into 8- $\mu \mathrm{m}$ sections and stained with haematoxylin and eosin or with periodic acid-Schiff (PAS)-haematoxylin. The brain tissues were sectioned between 12 and $25 \mu \mathrm{m}$ and stained with one of three methods: (1) the combined methods of Klüver \& Barrera (1953) for nerve cells and fibres, (2) thionine stain for Nissl substance (Fletcher, 1947), or (3) Weil-Weigert stain for myelin (Lillie, 1954).

\section{Electron microscopic study}

The pituitaries of four normal and four 'torpid' female mice between 3 and 4 months of age were exposed by removal of the calvarium and brain immediately after decapitation, and were fixed in a mixture of equal parts of ice-cold $2 \%$ paraformaldehyde buffered in cacodylate buffer solution $(0.2 \mathrm{M}, \mathrm{pH} 7.2)$ and $2 \%$ osmic acid mixture. After fixation for 6 to $8 \mathrm{hr}$, the tissues were kept in $0.5 \%$ ice-cold uranyl acetate solution overnight, and were then transferred to cold absolute alcohol for 5 to $12 \mathrm{hr}$. Two hr after the tissues were returned to room temperature, they were transferred to fresh absolute alcohol for a further $2 \mathrm{hr}$ and then placed in propylene oxide for $5 \mathrm{hr}$. All tissues were embedded in the plastic mixture recommended by Spurr (1969). Tissue blocks were cut into serial sections. Thin sections were mounted on copper grids with special 100 mesh (Ernest F. Fullam, Inc., Schenectady, New York). After staining with lead citrate, thin gold sections on grids were examined with the electron microscope. One good section was selected from every fifteen to twenty grids. A total of ten such sections were studied from each pituitary under a Siemens 1A or 101 electron microscope. Under a low magnification $(\times 2500)$, twelve negatives were taken from a grid, one from each mesh space. Each negative was printed to make a photograph with a final enlargement of $\times 10,000$ that of the original structures: P1. 2, Fig. 8 is typical of such prints. 
All cells showing profiles of their nuclei in the print were counted. These cells were then classified into (1) prolactin, (2) growth hormone, or (3) other cells. Growth hormone cells were the most prevalent and easy to identify (Rinehart \& Farquhar, 1953; Yamada \& Sano, 1960; Barnes, 1962).

\section{RESULTS}

Sources of the mutant stock and body weights

Text-figure 1 shows growth curves for normal and 'torpid' mice between 20 and 95 days of age.

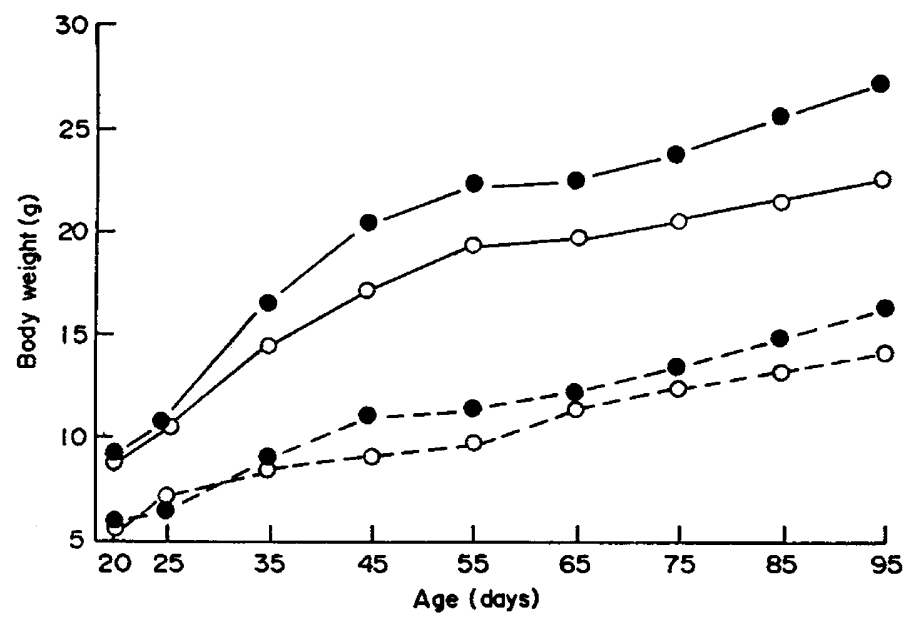

TExT-FIG. 1. Growth curves for phenotypically normal (-- - ) and 'torpid' (-- ) mice. Each dot or circle represents at least twelve and no more than fifteen animals.

- Males; O, females.

\section{Breeding records and low reproductivity}

When 55 pairs of normal mice $(\mathrm{TD} /+\times \mathrm{TD} /+$ ) bred, 54 litters were produced $(96.3 \%$ fertility). Breeding of normal males with mutant females (TD $/+\times$ tdtd) resulted in only five litters from 36 pairs $(13.8 \%$ fertility). Mutant males crossed with normal females $(\operatorname{tdtd} \times \mathrm{TD} /+)$ resulted in nine litters from 28 pairs $(32 \cdot 2 \%$ fertility).

\section{Vaginal smears}

All the normal females studied had regular oestrous cycles (Text-fig. 2). Similar regularity was observed in only $\frac{1}{6}$ 'torpid' females examined. Three of the mutant females studied exhibited no oestrous periods. Vaginal smears of these mice throughout the 30-day period contained only leucocytes.

\section{Organ weights}

No differences between the normal and 'torpid' mice were found for the weights of the brain, heart, kidney or spleen. The mean weight ( \pm S.E.M.) of the uterus $(\mathrm{mg} / 100 \mathrm{~g}$ body wt) was lower in 'torpid' $(55.54 \pm 9.58, \mathrm{~N}=9)$ than 
(a)

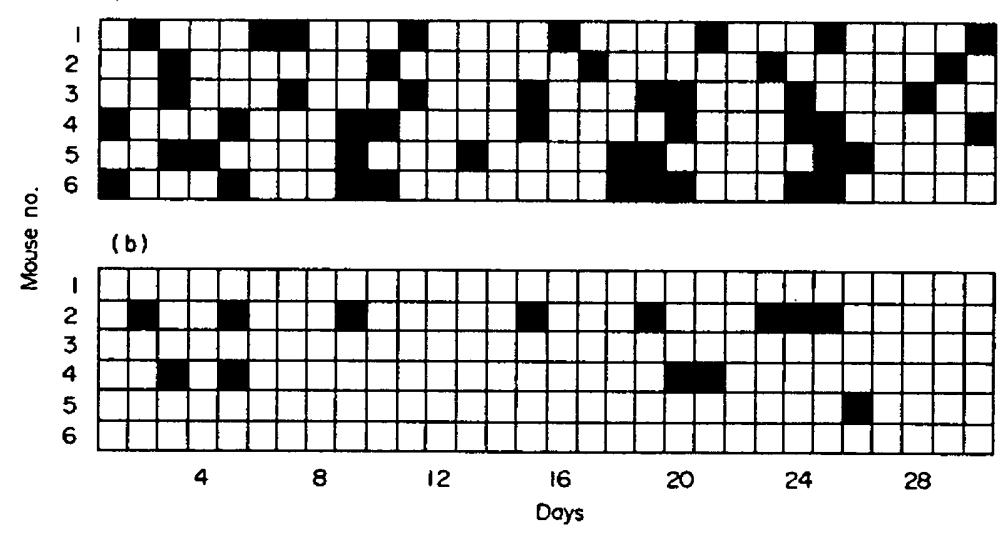

Text-Fig. 2. Periodicity of oestrus in (a) normal and (b) 'torpid' female mice. Filled-in squares represent periods of oestrus.

in normal $(79 \cdot 72 \pm 6 \cdot 58, \mathrm{~N}=9)$ mice, but the difference was not significant. The pituitary $(1 \cdot 70 \pm 0 \cdot 10, \mathrm{~N}=9)$ and ovary $(7 \cdot 05 \pm 0 \cdot 79, \mathrm{~N}=9)$ weights of 'torpid' mice were significantly different $(P<0.01$ and $P<0.001)$ from those of normal mice (pituitary: $2 \cdot 13 \pm 0 \cdot 20, \mathrm{~N}=9$; ovary: $11 \cdot 50 \pm 0 \cdot 84, \mathrm{~N}=9$ ).

\section{Histological and pathological studies}

The pituitary and ovaries showed consistent differences between 'torpid' and normal mice. Pathological changes characterized by degenerative involution were frequently observed in the thymus of the mutant.

In the ovaries of 'torpid' mice, corpora lutea were absent (Pl. 1, Fig. 1), although always present in the normal animals (Pl. 1, Fig. 2). Growing follicles of all sizes were found in the ovaries of 'torpid' mice, although the interstitial cells were dystrophic (PI. 1, Fig. 3) when compared to those of normal animals (Pl. 1, Fig. 4).

Histological differences between pituitaries of 'torpid' and normal mice were characterized by alterations in (1) the density of the cell population and (2) the nuclear/cytoplasmic ratio. The cells were smaller and more closely packed in the pituitary of 'torpid' (Pl. 1, Fig. 5) than in normal animals (Pl. 1, Fig. 6). This increase in the population density was associated with a scanty amount of cytoplasm in the pituitary cells. The pituitary cells were definitely larger in

\section{EXPLANATION OF PLATE 1}

Fig. 1. The ovary of a 'torpid' mouse. No corpora lutea are seen. $\mathrm{H} \& \mathrm{E}, \times 87$.

FIG. 2. The ovary of a normal littermate of a 'torpid' mouse showing a corpus luteum (CL). H \& E, $\times 87$.

Fic. 3. Interstitial cells taken from the central portion of the ovary shown in Fig. 1. $\mathrm{H} \& \mathrm{E}, \times 400$.

Fig. 4. Interstitial cells taken from the area between two corpora lutea shown in Fig. 2. $\mathrm{H} \& \mathrm{E}, \times 400$.

Fig. 5. A section of the pituitary of a female 'torpid' mouse. PAS, $\times 320$.

FIG. 6. A section of the pituitary of a female normal littermate of a 'torpid' mouse. PAS, $\times 320$. 


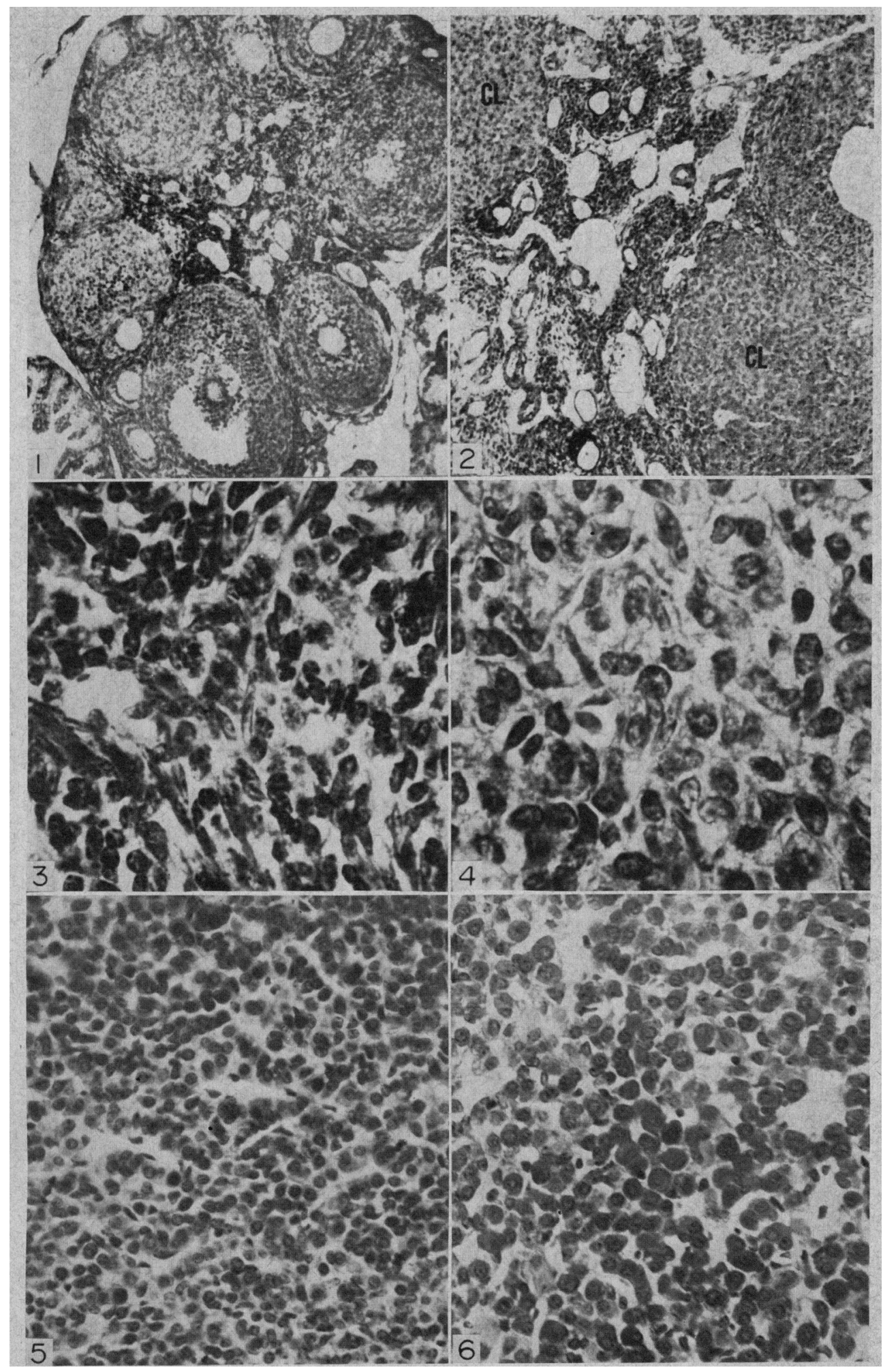

(Facing p. 94) 


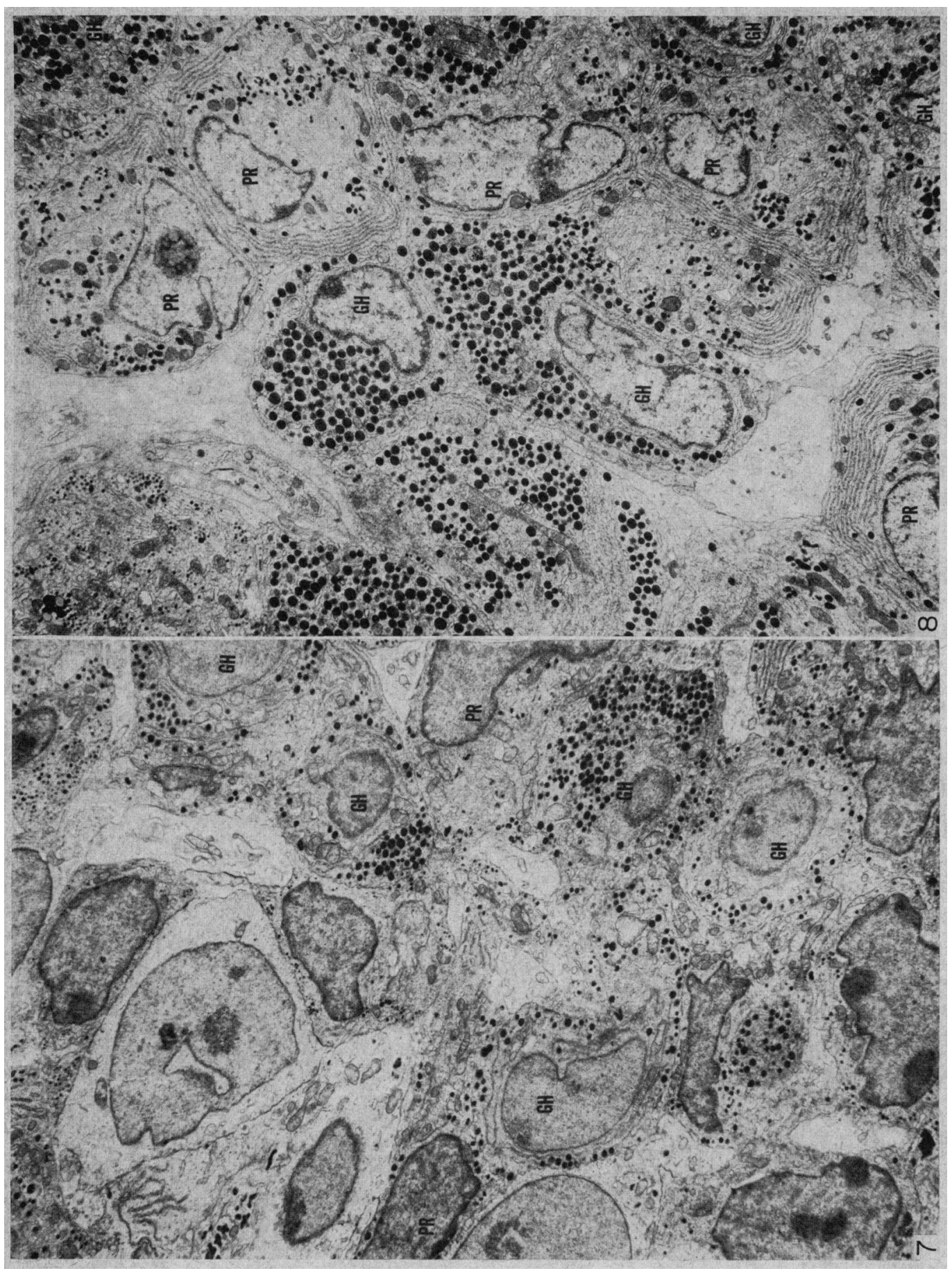

(Facing p. 95) 
normal mice than in the 'torpid' mice. The increase in the nuclear/cytoplasmic ratio reduced the distance between nuclei of pituitary cells and the cells became more closely packed.

\section{Electron microscope study}

Growth hormone cells were readily identified by their medium size, oval shape, and by the presence of many large round secretory granules. Their nuclei were round and were usually eccentrically placed within the cell.

Table 1. Numbers and percentages of the prolactin, growth hormone, and other cells in the pituitary of 'torpid' and littermate control mice at the age of 3 to 4 months

\begin{tabular}{|c|c|c|c|c|c|c|c|}
\hline \multirow{2}{*}{$\begin{array}{l}\text { Phenotype } \\
\text { of mice }\end{array}$} & \multirow{2}{*}{$\begin{array}{c}\text { Total no. } \\
\text { of cells counted }\end{array}$} & \multicolumn{2}{|c|}{ Prolactin cells } & \multicolumn{2}{|c|}{ Growth hormone cells } & \multicolumn{2}{|c|}{ Others } \\
\hline & & No. & $\%$ & No. & $\%$ & No. & $\%$ \\
\hline Control & $\begin{array}{r}783 \\
1106 \\
805 \\
1046\end{array}$ & $\begin{array}{l}241 \\
520 \\
383 \\
460\end{array}$ & $\begin{array}{l}30 \cdot 7 \\
46 \cdot 8 \\
47 \cdot 8 \\
44 \cdot 0\end{array}$ & $\begin{array}{l}252 \\
348 \\
307 \\
320\end{array}$ & $\begin{array}{l}32 \cdot 2 \\
31 \cdot 6 \\
37 \cdot 8 \\
30 \cdot 6\end{array}$ & $\begin{array}{l}290 \\
238 \\
115 \\
266\end{array}$ & $\begin{array}{l}37 \cdot 1 \\
21 \cdot 6 \\
14 \cdot 4 \\
25 \cdot 4\end{array}$ \\
\hline 'Torpid' & $\begin{array}{r}996 \\
846 \\
1260 \\
1179\end{array}$ & $\begin{array}{r}85 \\
118 \\
107 \\
90\end{array}$ & $\begin{array}{r}7 \cdot 8 \\
14 \cdot 0 \\
8 \cdot 5 \\
7 \cdot 6\end{array}$ & $\begin{array}{l}407 \\
369 \\
505 \\
438\end{array}$ & $\begin{array}{l}38 \cdot 3 \\
43 \cdot 6 \\
40 \cdot 1 \\
37 \cdot 2\end{array}$ & $\begin{array}{l}504 \\
359 \\
648 \\
651\end{array}$ & $\begin{array}{l}53 \cdot 9 \\
42 \cdot 4 \\
51 \cdot 4 \\
55 \cdot 2\end{array}$ \\
\hline
\end{tabular}

Prolactin cells were also easy to identify. They had pleomorphic granules which varied considerably in size. The endoplasmic reticulum of prolactin cells was always well developed in normal female mice. In the electron micrographs, the nuclei of prolactin cells often showed an indentation. After all of the cells had been classified and marked as prolactin, growth hormone, or other, the number of cells in the three categories was counted and tabulated. Table 1 contains the summary of the calculations derived from this study.

There were few prolactin cells in the pituitaries of 'torpid' female mice. In three of the four animals, they constituted less than $10 \%$ of the entire cell population in the gland. By comparison, prolactin cells in control animals accounted for more than $40 \%$ of the total cell population. No significant difference occurred in the growth hormone cells. A greater percentage of 'other' cell types was present in the pituitaries of 'torpid' mice compared to those of normal control mice. The pituitaries of 'torpid' mice had more cells which contained no granules (Pl. 2, Fig. 7) than the glands of normal controls (Pl. 2, Fig. 8).

The prolactin cells in the pituitary of 'torpid' mice usually contained fewer granules than those of control mice, although the size and shape of the granules

\section{EXPLANATION OF PLATE 2}

FIG. 7. A representative micrograph of the pituitary of a female 'torpid' mouse. Several growth hormone $(\mathrm{GH})$ cells are seen. There are only two cells which are identified as possible prolactin (PR) cells. $\times 6000$.

Fig. 8. A representative micrograph of the pituitary of a normal female littermate of 'torpid' mouse. A number of prolactin (PR) and growth hormone (GH) cells are seen. $\times 6000$. 
were unaffected. The lamellated endoplasmic reticulum was poorly developed and Golgi complexes were inconspicuous.

\section{DISGUSSION}

Approximately 100 mutant genes occurring in the mouse are known to produce behavioural abnormalities (tremor, paralysis, convulsions, seizures, instability of gait) in the affected animals. Because of these abnormalities, the mice are classified as neurological mutants (Sidman et al., 1965). The mutant 'torpid' mouse is one of them. Neurological mutant mice are considered to be important research animals for investigation of the nervous system, but histological examination of the nervous system of many mutants has failed to reveal pathological changes which can be taken as the cause of behavioural abnormalities. Typical examples are 'jittery', 'agitans', 'trembler', 'spastic', 'lethargic', and 'torpid' mutants (DeOme, 1945; Braverman, 1953; Martinez \& Sirlin, 1955; Chai, 1961; Dung \& Swigart, 1970). In 'tumbler', 'lethargic', and 'torpid' mutant mice, pathological changes are consistently found in some of the endocrine glands, reproductive organs, and lymphoid tissues. It seems that the usefulness of neurological mutant mice as research animals may not be in the nervous system, but rather in relation to endocrine malfunction, infertility, and immunological disorders. The literature reveals that, in addition to behavioural abnormalities, many mutant mice have three aspects of their conditions in common: growth retardation, low fertility, and frequent mortality around weaning age or at the 4 th week after birth. Examples of such mouse mutations are 'varitint-waddler' (Cloudman \& Bunker, 1945), 'jittery' (DeOme, 1945), 'trembler' (Falconer, 1951), 'reeler' (Falconer, 195I), 'ducky' (Snell, 1955), 'ataxia' (Lyon, 1955), 'quivering' (Yoon \& Les, 1957), 'waddler' (Yoon, 1959), 'tremulous' (Yoon, 1959), 'staggerer' (Sidman, Lane \& Dickie, 1962), 'spastic' (Chai, 1961), 'tumbler', 'lethargic' (Dung \& Swigart, 1970), and now 'torpid' mice.

Very little is known of the pathogenesis of the growth retardation, infertility, and high mortality of these different types of mutations. It was thought that difficulty in obtaining food and water due to the behavioural abnormalities probably resulted in the growth retardation and death of the affected animals (Falconer, 1951; Searle, 1952; Snell, 1955; Chai, 1961), but autopsies we have performed on 'torpid', 'lethargic', 'quaking', and 'tumbler' mice have shown that the stomachs and intestines contained food. A similar observation was made by DeOme (1945) in 'jittery' mutants. It is probable, therefore, that the growth retardation, infertility, and high mortality are due to other factors in addition to the difficulty in obtaining food.

The results of our experimental studies on a number of mouse mutations as well as those reported by other investigators seem to indicate that endocrine disturbances, particularly in the pituitary, may be involved in causing growth retardation and infertility, and that high mortality may be related to an immunological deficiency.

Two types of 'dwarf' mice (Snell, 1929; Schaible \& Gowen, 1961) are known to have growth retardation and infertility caused by pituitary deficiencies 
(Smith \& MacDowell, 1930, 1931; Kemp, 1938; Osborn, 1938; Marshak, 1938; Francis, 1944, 1945; Ortman, 1956; Rennels \& McNutt, 1958; Elftman \& Wegelius, 1959; Carsner \& Rennels, 1960; Cavallero et al., 1963; Bartke, $1964,1965 \mathrm{a}, 1965 \mathrm{~b}, 1965 \mathrm{c}, 1966 \mathrm{a}, 1966 \mathrm{~b})$. There is evidence to indicate that the high mortality of 'dwarf' mice is related to a selective deficiency in the cellmediated type of immunity which is thymus-dependent (Baroni, 1967; Duquesnoy et al., 1970). Other neurological mutations of the mouse which are known to have pathological changes in the pituitary include 'jittery' (DeOme, 1945), 'tumbler' (Dung \& Swigart, 1967), and 'lethargic'. The histology of the pituitary of these mutants is very similar to that of 'dwarf' mice. Their pituitary is congested and considerably more cellular than those of normal mice. Cell cytoplasm is scanty and nuclei are hyperchromatic. The pituitary from these three mutants as well as the other mouse mutations, except 'dwarf', has not been investigated thoroughly either by light or electron microscopy. In regard to a high mortality rate among affected mice, more types of mutations have been studied. All of those studies, including those for 'dwarf' mice, appear to indicate that a deficiency in immunity mechanisms involving a thymic involution and a severe lymphocytopenia may play an important role in causing early death in many mutant mice. DeOme (1945) reported that the thymus in 'jittery' mice is much smaller than that of the normal siblings and shows involutionary changes. He suggested that perhaps thymic involution was related to the cause of the malady of the 'jittery' mutant. Mufson \& Starr (1958) reported that 'wabbler-lethal' mice have lymphocytopenia, and therefore the mutants may be more susceptible to certain environmental factors which might play a role in initiating their disease. Mice carrying a new hairless gene described by Flanagan (1966) and studied by Pantelouris (1972) were found to show thymic involution and a deficiency in cell-mediated immunity. We reported that thymic involution occurred in 'tumbler' and 'lethargic' (Dung \& Swigart, 1970, 1971, 1972; Dung, 1973). It is possible that the pathological changes in the thymus are directly related to the high mortality of the mutant mice.

In the present study, 'torpid' mutant mice were found to have definite growth retardation between 20 and 95 days of age. Most of the mutants, male and female, were incapable of reproducing. Those female 'torpids' which were incapable of becoming pregnant were found to have either irregular oestrus cycles or none. Their pituitaries and ovaries were atrophic as shown by weight determination and histological examination. It is reasonable to suggest that 'torpid' mice have an endocrine deficiency, and their growth retardation and infertility may be caused by this rather than by behavioural difficulties in obtaining food and in copulation.

The nature and degree of specific pituitary hormone deficiencies which may be responsible for growth retardation and infertility in 'torpid' mice cannot be known from the present studies. Our electron microscopical studies on the pituitary suggest that a growth hormone deficiency may not be the main factor in causing the growth retardation and that further studies should be focused on the prolactin activity in 'torpid' mice. Prolactin is known to act synergistically with growth hormone in promotion of growth in animals, and it seems possible that the growth retardation in 'torpid' mice might be a result of 
prolactin deficiency in the animal. Infertility associated with a deficiency in prolactin activity is known in 'dwarf' mice (Bartke, 1965b, c, 1966a, b). Such a deficiency may also account for the low reproductive efficiency in female and male 'torpid' mice. It is, of course, quite possible that other hormones such as FSH and LH may be deficient in the mutant mice.

'Torpid' mice have a high mortality rate between 20 and 40 days of age, a period when the thymus often showed involutionary changes. More studies will be undertaken to determine if 'torpid' mice have any immunological deficit which may account for the increased mortality in these mutants.

\section{ACKNOWLEDGMENT}

The author thanks Mr Ben Castilleja for his technical assistance.

\section{REFERENCES}

BARNEs, B.G. (1962) Electron microscopic studies on the cytology of the mouse anterior pituitary. Endocrinology 71, 618-628.

BARoni, C. (1967) Thymus, peripheral lymphoid tissues and immunological responsiveness of the pituitary dwarf mouse. Experientia 23, 282-283.

BARTKE, A. (1964) Histology of the anterior hypophysis, thyroid and gonads of two types of dwarf mice. Anat. Rec. 149, 225-229.

Bartke, A. (1965a) Pregnancy, parturition and lactation in an Ames dwarf mouse. Genetics, Princeton 50,234

Bartke, A. (1965b) Absence of prolactin activity in pituitary of dwarf mice. Genetics, Princeton 52, 426427.

BartKe, A. (1965c) Influence of luteotrophin on fertility of dwarf mice. F. Reprod. Fert. 10, 93-103.

BARTKE, A. (1966a) Influence of prolactin on male fertility in dwarf mice. F. Endocr. 35, 419-420.

BARTKE, A. (1966b) Reproduction of female dwarf mice treated with prolactin. F. Reprod. Fert. 11, 203-206.

Braverman, I.M. (1953) Neurological actions caused by the mutant gene "trembler" in the house mouse (Mus musculus, L.) : an investigation. F. Neuropath. exp. Neurol. 12, 64-72.

Garsner, R.L. \& Rennels, E.G. (1960) Primary site of gene action in anterior pituitary dwarf mice. Science, N.Y. 131, 829.

Cayallero, G., Martinazzi, M., Baroni, C. \& Magrini, U. (1963) Pituitary control of mouse testis in hereditary dwarfism: histological and cytochemical observations. Gen. E compar. Endocr. 3, 636-643.

CHAI, C.K. (1961) Hereditary spasticity in mice. F. Hered. 52, 241-243.

Cloudman, A.M. \& Bunker, L.E., JR. (1945) The varitint-waddler mouse. A dominant mutation in Mus musculus. F. Hered. 36, 259-263.

DeOme, K.B. (1945) A new recessive lethal mutation in mice. Univ. Calif. Publs Zool. 53, 41-65.

DickiE, M.M. (1965) "Torpid" mutant mice. Mouse Newes Letter 32, 45.

Dung, H.C. (1973) Electron microscopic study of involuting thymus of "lethargic" mutant mice. Anat. Rec. 177, 585-601.

Dung, H.C. \& SwigarT, R.H. (1970) Studies of mutant mice with symptoms resembling wasting disease following neonatal thymectomy. Anat. Rec. 166, 300.

Dung, H.C. \& Swigart, R.H. (1971) Experimental studies of "lethargic" mutant mice. Texas Rep. Biol. Med. 29, 273-288.

Dung, H.G. \& Swigart, R.H. (1972) Histo-pathologic observations of the nervous and lymphoid tissues of "lethargic" mutant mice. Texas Rep. Biol. Med. 30, 23-39.

Duquesnoy, R.J., Kalpaktsoglon, P.K. \& Good, R.A. (1970) Immunological studies of the SnellBagg pituitary dwarf mouse. Proc. Soc. exp. Biol. Med. 133, 201-206.

Elftman, H. \& Wegerius, O. (1959) Anterior pituitary cytology of the dwarf mouse. Anat. Rec. 135, $43-47$.

FALCONER, D.S. (1951) Two new mutants, "trembler" and "reeler", with neurological actions in the house mouse (Mus musculus, L.). F. Genet. 50, 192-201.

Flanagan, S.P. (1966) 'Nude', a new hairless gene with pleiotropic effects in the mouse. Genet. Res, 8, 295-309. 
FLETCHER, D.E. (1947) Rapid staining procedures for paraffin sections of formalin fixed nervous tissue. 7. Neuropath. exp. Neurol. 6, 299-305.

Francis, T. (1944) Studies on hereditary dwarfism in mice. VI. Anatomy, histology and development of the pituitary at hereditary anterior pituitary dwarfism in mice. Acta path. microbiol. scand. 21, 928-945.

Francrs, T. (1945) Studies on hereditary dwarfism in mice. VIII. The histology of the anterior pituitary of mice with hereditary adiposity and of dwarf mice with hereditary adiposity. Acta path. microbiol. scand. 22, 138-143.

KEMP, T. (1938) Hereditary and endocrine function. An investigation of hereditary pituitary deficiency in the mouse. Acta pathol. microbiol. scand., Suppl. 14, 290-305.

Kluver, H. \& BARRERA, E. (1953) A method for the combined staining of cells and fibers in the nervous system. F. Neuropath. exp. Neurol. 12, 400-403.

Lilue, R.D. (1954) Histopathologic Technic and Practical Histochemistry. Blackston Company, New York.

Lyon, M.F. (1955) Ataxia - a new recessive mutant of the house mouse. F. Hered. 46, 77-80.

Marshak, A. (1938) Gonadotropic hormones in the hereditary dwarf mouse. Proc. Soc. exp. Biol. Med. $38,226-228$.

Martinez, A. \& Sirlin, J.L. (1955) Neurohistology of the agitans mouse. F. comp. Neurol. 103, 131-137.

Murson, M.A. \& STARR, A. (1958) Abnormal myelin and leucopenia in the wabbler-lethal mouse. 7. Hered. 49, 233-237.

Ortman, R. (1956) A study of some cytochemical reactions and the hormonal content of the adenohypophysis in normal and in genetic dwarf mice. 7. Morph. 99, 417-431.

OsBoRn, C.M. (1938) Experimentally induced ovulation in dwarf mice. Endocrinology 22, 370-373.

PANTELouris, E.M. (1972) Thymic involution and ageing: a hypothesis. Expl Geront. 7, 73-81.

RENnELs, E.G. \& MCNuTt, M. (1958) The fine structure of the anterior pituitary of the dwarf mouse. Anat. Rec. 131, 591-592.

Rinehart, J.F. \& FARQUHAR, M.G. (1953) Electron microscopic studies of the anterior pituitary gland. J. Histochem. Cytochem. 1, 93-113.

Schaible, R. \& Gowen, J. W. (1961) A new dwarf mouse. Genetics, Princeton 46, 896.

SeArle, A.G. (1952) A lethal allele of dilute in the house mouse. Heredity 6, 395-401.

Sidman, R.L., Lane, P.W. \& Dickie, M.M. (1962) Staggerer, a new mutation in the mouse affecting the cerebellum. Science, $\mathcal{N}$.X. 137, 610-612.

Sidman, R.L., Green, M.C. \& AppeL, S.H. (1965) Catalog of Neurological Mutants of the Mouse. Harvard University Press, Cambridge, Massachusetts.

Smith, P.E. \& MacDowell, E.C. (1930) An hereditary anterior pituitary deficiency in the mouse. Anat. Rec. 46, 249-257.

Smith, P.E. \& MAcDoweLL, E.C. (1931) The differential effect of hereditary mouse dwarfism on the anterior pituitary hormones. Anat. Rec. 50, 85-93.

SNELI, G.D. (1929) Dwarf, a new mendelian recessive character of the house mouse. Proc. natn. Acad. Sci. U.S.A. 15, 733-734.

SNELL, G.D. (1955) Ducky, a new second chromosome mutation in the mouse. F. Hered. 46, 27-29.

SPURR, A.R. (1969) A low-viscosity epoxy resin embedding medium for electron microscopy. 7 . Ultrastruct. Res. 26, 31-43.

YAMADA, K. \& SANO, N. (1960) Electron microscopic observations of the anterior pituitary of the mouse. Okajimas Folia anat. jap. 34, 449-458.

Yoon, C.H. (1959) Waddler, a new mutation and its interaction with quivering. F. Hered. 50, 238-244.

Yoon, C.H. \& Les, E.P. (1957) Quivering, a new first chromosome mutation in mice. F. Hered. 48, 176-180. 